\title{
FORMING-LIMIT DIAGRAMS AND STRAIN-RATE-DEPENDENT MECHANICAL PROPERTIES OF AA6019-T4 AND AA6061-T4 ALUMINIUM SHEET MATERIALS
}

\author{
MEJNI DIAGRAMI PREOBLIKOVANJA IN ODVISNOST \\ MEHANSKIH LASTNOSTI OD HITROSTI PREOBLIKOVANJA \\ ALUMINIJEVIH PLOČEVIN IZ AA6019-T4 IN AA6061-T4
}

\author{
Onur Çavuşoğlu ${ }^{1,2}$, Alan Gordon Leacock ${ }^{2}$, Hakan Gürün ${ }^{1}$ \\ ${ }^{1}$ Gazi University, Faculty of Technology, Department of Manufacturing Engineering, Ankara, Turkey \\ ${ }^{2}$ University of Ulster, Advanced Metal Forming Research Group (AMFOR), Newtonabbey, Northern Ireland \\ onur.cavusoglu@gazi.edu.tr \\ Prejem rokopisa - received: 2015-08-17; sprejem za objavo - accepted for publication: 2015-27-10
}

doi:10.17222/mit.2015.259

\begin{abstract}
The mechanical properties and formability behaviour of sheet materials depend on the deformation conditions. In this study, the variance of AA6019-T4 and AA6061-T6 aluminium sheet materials related to the strain rate of their mechanical properties was studied by applying uniaxial tensile tests on these materials at different semi-static strain rates $\left(0.3 \mathrm{~s}^{-1}, 0.03 \mathrm{~s}^{-1}, 0.003 \mathrm{~s}^{-1}\right.$, $\left.0.0003 \mathrm{~s}^{-1}, 0.00003 \mathrm{~s}^{-1}\right)$. In addition, forming-limit diagrams of these materials were determined by applying Nakajima tests. When the results were analysed, it was found that the strain rate developed some mechanical properties in the AA6019-T4 and AA6061-T4 sheet materials and that the AA6061-T4 sheet material has a higher formability capability in comparison with the AA6019-T4 sheet material.

Keywords: FLD, strain rate, aluminium alloy 6061, aluminium alloy 6019
\end{abstract}

Mehanske lastnosti in obnašanje pri preoblikovanju pločevine sta odvisna od pogojev deformacije. V študiji je bilo proučevano spreminjanje AA6019-T4 in AA6061-T6 aluminijeve pločevine glede na hitrost preoblikovanja in proučevane so bile njihove mehanske lastnosti z uporabo enoosnih nateznih preizkusov teh materialov pri različnih semi-statičnih hitrostih preoblikovanja $\left(0.3 \mathrm{~s}^{-1}, 0.03 \mathrm{~s}^{-1}, 0.003 \mathrm{~s}^{-1}, 0.0003 \mathrm{~s}^{-1}, 0.00003 \mathrm{~s}^{-1}\right)$. Dodatno so bili določeni še diagrami mejnega preoblikovanja teh materialov $\mathrm{z}$ uporabo Nakajima preizkusov. Analiza dobljenih rezultatov je pokazala, da hitrost preoblikovanja vpliva na mehanske lastnosti AA6019-T4 in AA6061-T4 pločevin in da ima AA6061-T4 pločevina večjo sposobnost preoblikovanja v primerjavi s pločevino AA6019-T4.

Ključne besede: FLD, hitrost deformacije, aluminijeva zlitina 6061, aluminijeva zlitina 6019

\section{INTRODUCTION}

Great importance is attached to weight-reduction technology at the present time. For this reason, studies on the reduction of the amount of vehicle fuel consumption and $\mathrm{CO}_{2}$ emissions have been analysed. It has been observed in the studies conducted for this purpose that improved high-strength steels and light-metal materials such as aluminium and magnesium alloys have an important place. ${ }^{1,2}$ When the usage applications of aluminium alloys are analysed, it is clear that they have been commonly preferred in the automotive and aerospace industries on account of their superior characteristics, such as their low density, high strength, formability, corrosion resistance and high availability as a source., ${ }^{2,3}$

Tensile testing is a method commonly used for determining a plurality of mechanical properties and the deformation behaviour of the materials. Many parameters obtained from the tensile test may vary, based on the material's deformation conditions, such as friction, deformation speed and temperature. ${ }^{4}$ It is known that the strain rate changes many metallic materials' properties by affecting the relation between the tensile and deformation. ${ }^{3}$ Studies about the effects of the strain rate on the mechanical properties of aluminium alloys are available in the literature. J. Q. Tan et al..$^{5}$ analysed the tensile behaviour at high strain rates by using 7050-T7451 aluminium alloy, and they determined that an increasing deformation rate increases the amount of tensile. M. Vural and J. Caro ${ }^{6}$ observed, by analysing the tensile behaviour of 2139-T8 aluminium alloy at different temperatures and deformation rates, that a significant change in the behaviour of materials at low strain rates does not occur and that the yield stress at high deformation rates increases. By applying tensile tests on the AA5754 and AA5182 aluminium alloys, Smerd and others have found that when high deformation rates subtract from the semi-static strain rates of the AA5754 aluminium alloy, there is no change among the high strain rates, while a significant increase in the yield stress occurs, and they also found that the AA5182 alloy is not completely affected by changes in the strain rates. However, the increasing strain rate increases the amount of stretching in both alloys. ${ }^{7}$ In their study O. G. Lademo et al. ${ }^{8}$ 
determined that an increase in the tensile strength and elongation occurs by analysing the strain rate sensitivity of the AA1200 and AA3103 aluminium alloys, although the yield strength is not affected, depending on the increase in the deformation rate. In their study, D. Li and A. Ghosh ${ }^{9}$ determined the mechanical properties of aluminium alloys at different temperatures and strain rates.

Forming-limit diagrams (FLDs) must be determined in order to assess the behaviour of the sheet's formability during the sheet material's characterization. The Nakajima test is widely preferred for the determination of the forming-limit diagram. Deforming the sheet with a hemispherical punch until the sheet material, for different geometries, starts to neck in the Nakajima test and measuring changes to the shape occurring in a predetermined grid on the sheet material can be obtained using forming-limit diagrams. In this process, deformations of uniaxial plane strain and biaxial stretching deformations occur in the sheet material. ${ }^{10,11}$

The parameters of the deformation, such as the temperature and strain rate, affecting the mechanical properties of materials affect the formability of sheet material and therefore also affect the forming-limit diagrams. In their studies, C. Zang et al. ${ }^{12,13}$ determined, by analysing the FLDs of AA5086 and AA5083 aluminium alloys at elevated temperatures and at different strain rates, that the ability of formability decreases due to the increase in the strain rate. T. Naka et al. ${ }^{14}$ in their study looked at the 5083 magnesium-aluminium alloy at different temperatures and strain rates and reported that the strain rates decrease the formability at high temperatures, but a significant effect is not observed at room temperature.

Considering the studies in the literature; it has been seen in the majority of aluminium alloys that an increase in the strain rate improves some of the mechanical pro- perties, whereas analysing its effects on the forminglimit diagrams and the strain rate at room temperature is understood not to have a significant effect. ${ }^{4-8,12-14}$

In this study, it is intended to bring in the literature AA6019-T4 and AA6061-T4 aluminium alloy sheet materials whose mechanical properties have been determined, and whose forming-limit diagram has been obtained.

\section{MATERIAL AND EXPERIMENTAL METHODS}

\subsection{Material}

AA6061-T4 and AA6019-T4 sheet metal materials that are Al-Mg-Si-based are used in the study conducted. The chemical composition of these materials is given in Table 1. Also, microstructure photographs taken during the rolling, transverse and diagonal directions of the sheet materials are shown in Figures $\mathbf{1}$ and 2. The specimens for the optical investigations were etched using a mixture of acetic acid $(7 \mathrm{~mL})$, picric acid $(25 \mathrm{~g})$, ethanol $(140 \mathrm{~mL})$, and purified water $(40 \mathrm{~mL})$ for $15 \mathrm{~s}$ to reveal the microstructure.

Tensile test samples were prepared according to ASTM E517 standards in order to determine the mechanical properties of the material depending on the strain rate. The standard size is shown for the tensile test in Figure 3. It is carried out according to the Nakajima test method for forming-boundary limits. Thus, test samples that have been prepared according to the ASTM E 2218-02 standard are used. The Nakajima test-sample dimensions are shown in Table 2. The cutting process was performed in a water-jet machine in order to minimize the thermal impacts that may occur on the sheet material during the preparation of the test samples. Also, the notch effect, which may occur during deformation,

Table 1: Chemical composition of AA6019-T4 and AA6061-T4 sheet metal material, in mass fractions (w/\%)

Tabela 1: Kemijska sestava AA6019-T4 in AA6061-T4 pločevin, v masnih odstotkih (w/\%)

\begin{tabular}{|c|c|c|c|c|c|c|c|c|c|}
\hline Material & $\mathrm{Mg}$ & $\mathrm{Si}$ & $\mathrm{Fe}$ & $\mathrm{Cu}$ & $\mathrm{Cr}$ & $\mathrm{Mn}$ & $\mathrm{Ti}$ & $\mathrm{Zn}$ & $\mathrm{Al}$ \\
\hline AA 6061-T4 & 0.8 & 0.4 & 0.5 & 0.15 & 0.15 & $<0.15$ & $<0.15$ & $<0.25$ & balance \\
\hline AA 6019-T4 & 1.2 & 0.1 & $<0.5$ & 0.6 & 0.35 & $<0.1$ & $<0.15$ & 0.1 & balance \\
\hline
\end{tabular}
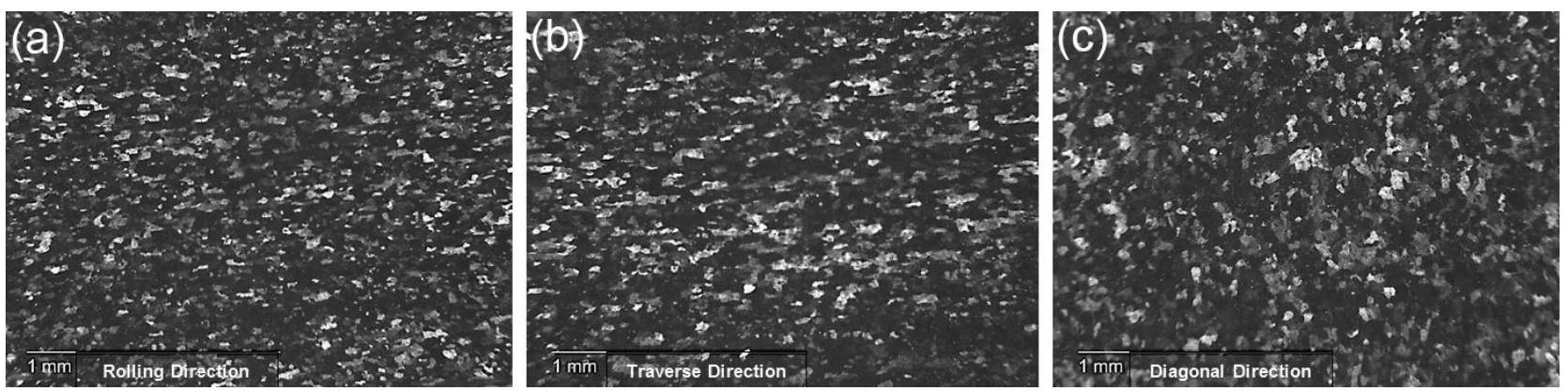

Figure 1: Microstructure photos of AA6061-T4

Slika 1: Posnetki mikrostrukture AA6061-T4 

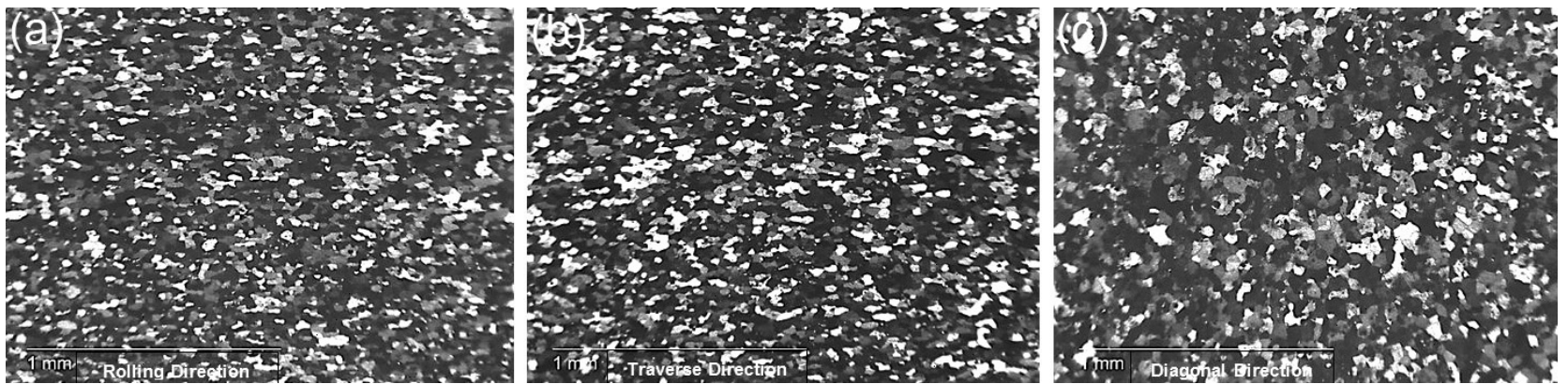

Figure 2: Microstructure photos of AA6019-T4

Slika 2: Posnetki mikrostrukture AA6019-T4

was eliminated by polishing the side surface of the test sample.

Table 2: Nakajima test sample sizes

Tabela 2: Velikost vzorcev za Nakajima preizkus

\begin{tabular}{|c|c|c|}
\hline Nakajima specimen & Sample No. & $R(\mathrm{~mm})$ \\
\hline & 1 & 0 \\
\hline & 2 & 20 \\
\hline & 3 & 40 \\
\hline & 4 & 50 \\
\hline & 5 & 57.5 \\
\hline & 6 & 65 \\
\hline & 7 & 72.5 \\
\hline & 8 & 80 \\
\hline
\end{tabular}

\subsection{Experimental methods}

\subsubsection{Tensile test}

Tensile test samples of the AA6019-T4 and AA6061-T4 metal material sheet were prepared according to ASTM E517 standards. The tensile tests were carried out at room temperature using a mechanical deformation meter in an Instron 5500 tensile test device.

Tensile tests were carried out for three different directions (RD, TD, DD) and five different strain rates $\left(0.3 \mathrm{~s}^{-1}, 0.03 \mathrm{~s}^{-1}, 0.003 \mathrm{~s}^{-1}, 0.0003 \mathrm{~s}^{-1}, 0.00003 \mathrm{~s}^{-1}\right)$. The average values were taken by repeating each test three times for each sheet material and each different deformation rate in order to reduce the margin of error. As a result of these tests, the yield strength, tensile strength, strain-hardening coefficient, total elongation and anisotropy values were obtained, depending on the strain rates from the the true stress vs. true strain curves of the sheet material.

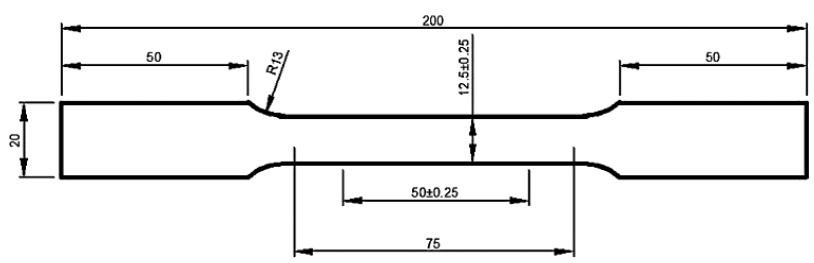

Figure 3: ASTM E517 tensile test specimen dimensions Slika 3: Dimenzije nateznega preizkušanca po ASTM E517

\subsubsection{Forming-limit diagrams (FLDs)}

In the second part of the study, the forming-limit diagrams were obtained using the Nakajima test method in order to determine the formability capabilities of AA6019-T4 and AA6061-T4 sheet metal. A schematic view of the Nakajima test method is presented in Figure 4.

A 2.4-mm-diameter circular gridding process using an electrochemical etching method was performed on the upper surfaces of the samples for these tests. Then, the hydraulic bulging process was applied on the test samples with a hemispherical punch until the fracture on

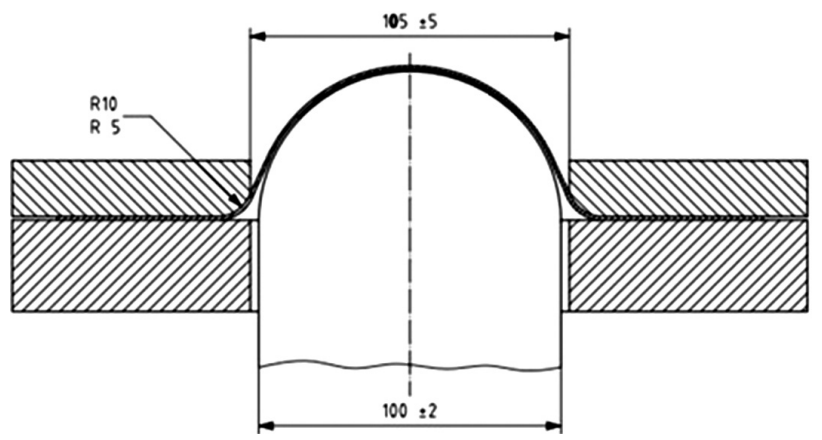

Figure 4: Nakajima test method's schematic display of forming limit diagram

Slika 4: Shematski prikaz Nakayima preizkusa za mejni diagram preoblikovanja

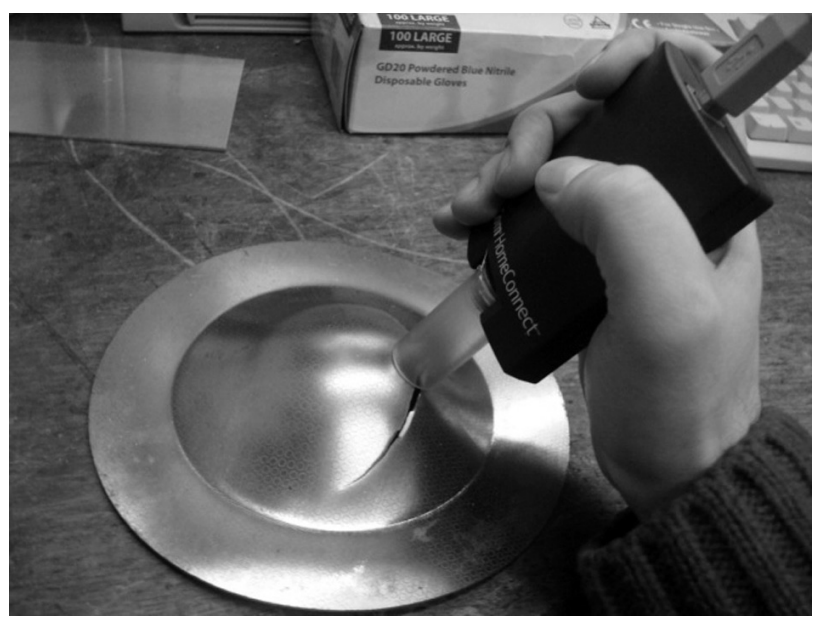

Figure 5: The measurement of the grid Slika 5: Merjenje mreže 
the sheet material occurred. The measurement process of the samples proceeded in order to determine the plastic deformation occurring in the grid. The measurement processes was carried out by means of the measuring system at the University of Ulster, Northern Ireland. A photograph of the performed measurement process is presented in Figure 5. The grids in which the deformation occurs on the sheet material were computerized by measuring with the help of a camera and a 3.0 GPA program. After this, the forming-limit diagrams were determined by processing the data.

\section{RESULTS AND DISCUSSION}

\subsection{Tensile test results}

The variance of the sheet materials' mechanical properties depending on the strain rate is determined by applying the tensile tests at $\left(0.3 \mathrm{~s}^{-1}, 0.03 \mathrm{~s}^{-1}, 0.003 \mathrm{~s}^{-1}\right.$, $\left.0.0003 \mathrm{~s}^{-1}, 0.00003 \mathrm{~s}^{-1}\right)$ strain rates. The data obtained from the tensile-test results are given in Tables 3 and 4 .

Table 3: AA6019-T4 tensile test results

Tabela 3: Rezultati nateznega preizkusa AA6019-T4

\begin{tabular}{|c|c|c|c|c|c|}
\hline $\begin{array}{c}\text { Strain } \\
\text { rate }\end{array}$ & $\begin{array}{c}\text { Yield } \\
\text { strength }\end{array}$ & $\begin{array}{c}\text { Tensile } \\
\text { strength }\end{array}$ & $\begin{array}{c}\text { Hardening } \\
\text { coefficient }\end{array}$ & $\begin{array}{c}\text { Elon- } \\
\text { gation }\end{array}$ & R value \\
\hline 0.3 & 224 & 399 & 0.23 & 0.15 & 0.291 \\
\hline 0.03 & 221 & 397 & 0.24 & 0.17 & 0.316 \\
\hline 0.003 & 219 & 396 & 0.23 & 0.17 & 0.384 \\
\hline 0.0003 & 220 & 397 & 0.24 & 0.17 & 0.446 \\
\hline 0.00003 & 219 & 390 & 0.22 & 0.18 & 0.469 \\
\hline
\end{tabular}

Table 4: AA6061-T4 tensile test results

Tabela 4: Rezultati nateznega preizkusa AA6061-T4

\begin{tabular}{|c|c|c|c|c|c|}
\hline $\begin{array}{c}\text { Strain } \\
\text { rate }\end{array}$ & $\begin{array}{c}\text { Yield } \\
\text { strength }\end{array}$ & $\begin{array}{c}\text { Tensile } \\
\text { strength }\end{array}$ & $\begin{array}{c}\text { Hardening } \\
\text { coefficient }\end{array}$ & $\begin{array}{c}\text { Elon- } \\
\text { gation }\end{array}$ & R value \\
\hline 0.3 & 165 & 325 & 0.25 & 0.18 & 0,46 \\
\hline 0.03 & 165 & 322 & 0.24 & 0.18 & 0.468 \\
\hline 0.003 & 162 & 324 & 0.25 & 0.19 & 0.479 \\
\hline 0.0003 & 164 & 325 & 0.24 & 0.20 & 0.555 \\
\hline 0.00003 & 155 & 310 & 0.25 & 0.21 & 0.649 \\
\hline
\end{tabular}

The relationship between the strain rate of the AA6019 -T4 and AA6061-T4 sheet materials and the yield strength is given in Figure 6. An increase in the yield strength of the sheet materials occurs with an increased strain rate. ${ }^{5-7}$ Upon analysing Figure 6, it is seen that the yield strength of both sheet materials shows an upward tendency with the strain rate. By considering the amounts of increase in the yield strength, the AA6019-T4 sheet material's yield strength was determined to be between $220 \mathrm{MPa}$ and $225 \mathrm{MPa}$ at the lowest $\left(0.00003 \mathrm{~s}^{-1}\right)$ and the highest $\left(0.3 \mathrm{~s}^{-1}\right)$ strain rates. It is determined that the AA6061-T4 sheet material has the lowest yield strength at the lowest $\left(0.00003 \mathrm{~s}^{-1}\right)$ strain-rate value. At the other strain rates it is clear that the detected values of the yield strength were between $163 \mathrm{MPa}$ and $166 \mathrm{MPa}$. According to these results, it is

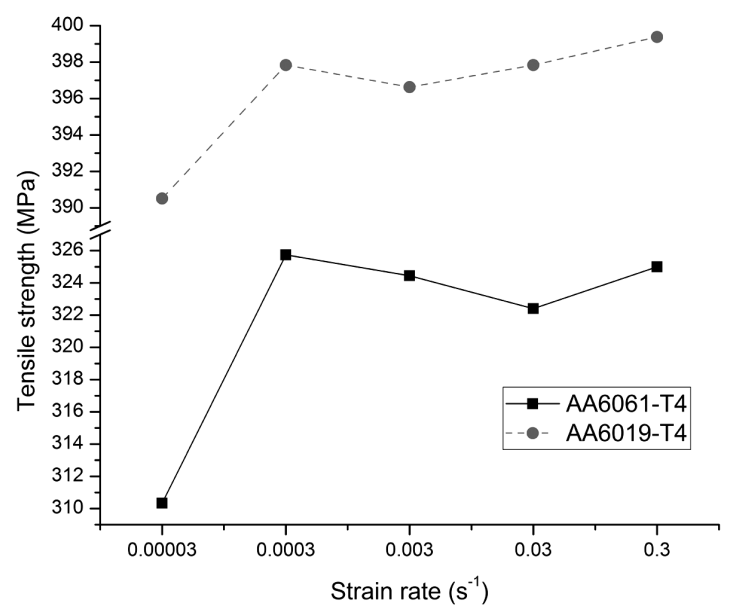

Figure 6: Strain rate vs. yield strength

Slika 6: Odvisnost med hitrostjo preoblikovanja in mejo plastičnosti

observed that the yield strength of AA6019-T4 and AA6061-T4 sheet materials was not significantly affected by the increase in the strain rate.

Tensile strength is one of the most important parameters in the classification of sheet materials. The strain rate vs. tensile strength relationship is shown in Figure 7. Analysing the effects of the strain rate on the tensile strength, it is determined that both sheet materials have the lowest tensile strength at the lowest deformation rate. The tensile strength also increased with an increase in the strain rate. However, very small amounts of change in the tensile strength were seen at the other strain rates. In studies in the literature, it is determined that an increase occurred in the tensile strength with an increasing strain rate, but this increase was very small at room temperature. ${ }^{5,8}$ Also in this study, when the tensile strength obtained at the lowest deformation rate for the AA6019-T4 and AA6061-T4 sheet materials used in the experiments was compared with the other strain rates in the tensile strength values, it is clear that the tensile strength of both sheet materials increased by a small amount.

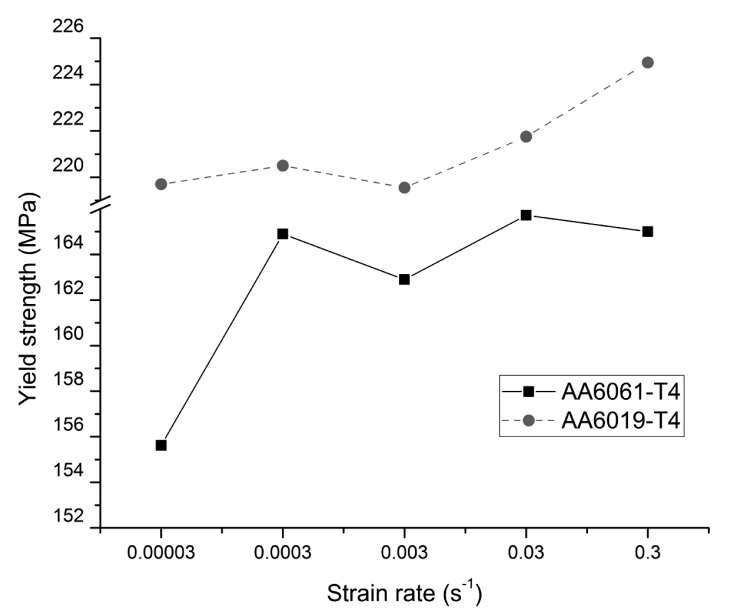

Figure 7: Strain rate vs. tensile strength

Slika 7: Odvisnost med hitrostjo preoblikovanja in natezno trdnostjo 


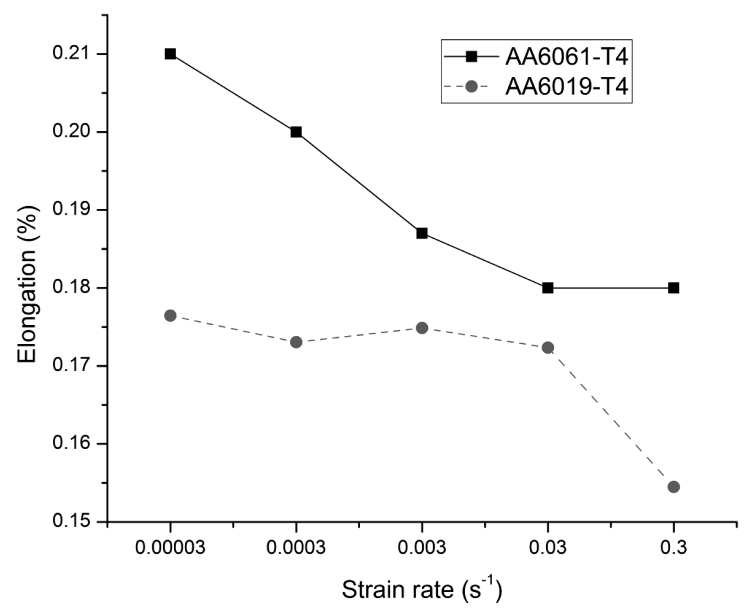

Figure 8: Strain rate vs. elongation

Slika 8: Odvisnost med hitrostjo deformacije in raztezkom

As a result of the performed tensile tests, the strain rate vs. total elongation graphs of the AA6019-T4 and AA6061-T4 sheet materials are given in Figure 8. When the graphics are analysed, the maximum elongation of the AA6019-T4 sheet material occurred at the lowest strain rate of the total elongation. For the other deformation rates, it is seen to be unaffected by the changes at the strain rates. When the AA6061-T4 sheet material's elongation behaviour was analysed, it is clear that the increasing strain rate and total elongation have a downward tendency. Upon comparing the elongation behaviour of the two materials, it is seen that the AA6019-T4 sheet material has elongated less than the AA6061-T4 sheet material. Upon analysing sheet materials in the same series, it is seen that sheet materials having a high tensile strength elongated less.

The materials gain strength through strain hardening during the plastic deformation of the sheet-metal material. Upon analysing graphs of the strain rate vs. strain hardening coefficient in Figure 9, it is clear that strainhardening coefficient was in the range $0.22-0.24$ for the

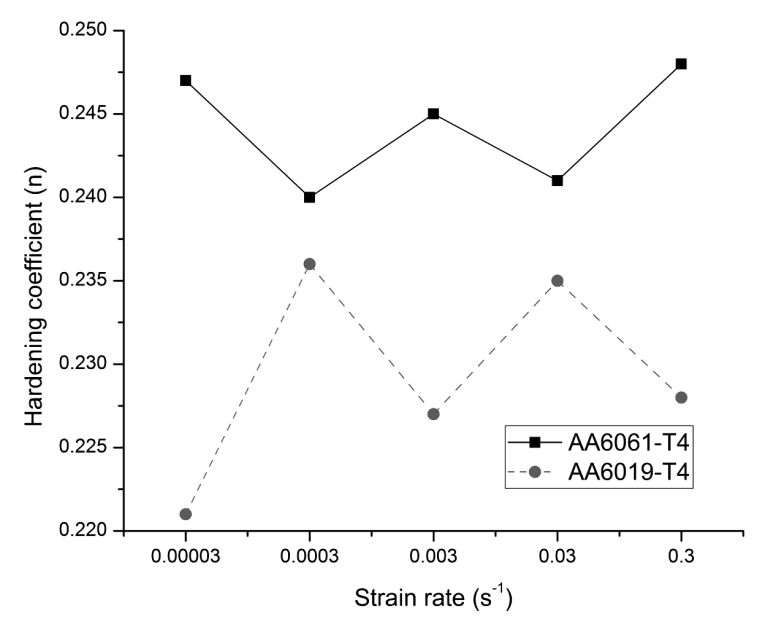

Figure 9: Strain rate vs. hardening coefficient

Slika 9: Odvisnost med hitrostjo preoblikovanja in koeficientom utrjevanja

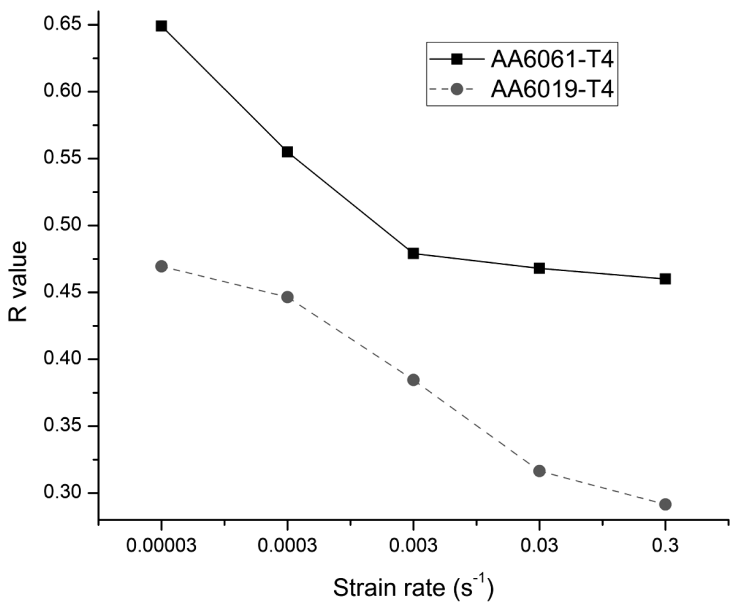

Figure 10: Strain rate vs. anisotropy

Slika 10: Odvisnost med hitrostjo preoblikovanja in anizotropijo

AA6019-T4 sheet material, and $0.24-0.25$ for the AA6061-T4 sheet material. Also, it is clear that the strain-hardening coefficient of both sheet materials was not significantly affected by the variance in the deformation rate. The strain-hardening coefficient results in the study of D. Li and A. Ghosh ${ }^{9}$ shows that it has changed over a very small range. Therefore, the results obtained were found to be consistent with the literature.

When analysing the average planer anisotropy values in Figure 10, it is seen that an amount of decrease has occurred in the plane anisotropy and increasing deformation speed. However, when evaluating the plane anisotropy coefficients, the values were found to be close to each other. It was concluded that the plane anisotropy coefficient in both sheet materials shows a slight downward tendency.

\subsection{Forming-limit diagram}

Upon analysing the results obtained from tensile tests, both experimental sheet materials used in this study were determined not to have been significantly affected by the variance in the strain rate. Therefore, the forming-limit diagrams of the AA6019-T4 and AA6061-T4 sheet materials were determined by Nakajima Tests by considering the strain rate $0.003 \mathrm{~s}^{-1}$ $(10 \mathrm{~mm} / \mathrm{s})$. Forming-limit diagrams are shown in Figure 11.

The area under the forming-limit diagrams represents a safety forming area. The upper parts of the curve show the areas occurring for the fracture in the sheet material. ${ }^{11-13}$ Upon evaluating the forming-limit diagram in Figure 11, it is clear that the AA6061-T4 sheet material has higher deformation limits than the AA6019-T4 sheet material, by showing higher elongation behaviour than the latter. Thus, it provides that the forming-limit curve obtained for the AA6061-T4 sheet material was above the AA6019-T4 sheet metal's forming-limit curve. This case shows that the AA6061-T4 sheet material had better formability. And this case constitutes solid-solu- 


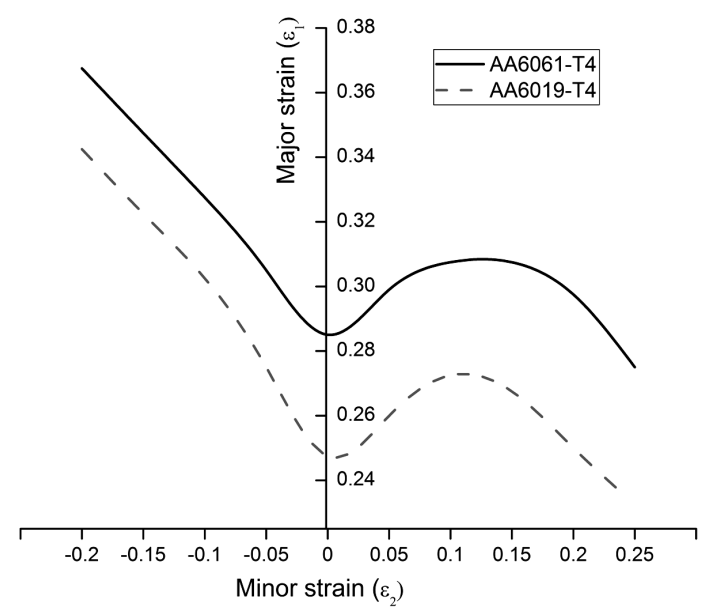

Figure 11: Forming-limit diagrams

Slika 11: Diagrami meje preoblikovanja

tion strengthening, owing to the fact that the rate of alloying elements in the chemical composition of the AA6019-T4 sheet material was higher than the AA6061-T4 sheet material. This also ensures that it has a higher yield and tensile strength and causes the ability of formability to decrease. Furthermore, the AA6061-T4 sheet material had greater elongation and anisotropy $(R)$ values than the AA6019-T4 sheet material, which is another sign that the former has a higher formability than the latter.

\section{CONCLUSIONS} below.

The results obtained from this study are summarized

The lowest values for both the yield and tensile strength of the sheet material are obtained at the lowest deformation rate $\left(0.00003 \mathrm{~s}^{-1}\right)$. It is found that as long as the strain rate increases, the yield and tensile strengths show a slight increase.

A very small range of change in the strain-hardening coefficient is observed with an increase in the strain rate.

A downward tendency is seen in both sheet materials' elongation, the plane anisotropy upon the increase of the strain rate. However, the exchange range of the elongation and the plane anisotropy are found to be too narrow. Therefore, it can be said that the AA6061-T4 and AA6019-T4 sheet materials are insensitive to the strain rate.

AA6061-T4 aluminium alloy is found to have higher formability limits than the AA6019-T4 aluminium alloy.

\section{Acknowledgement}

The authors would like to thank Turkish Council of Higher Education for the research grant and University of Ulster, Advanced Metal Forming Research Group (AMFOR) for the necessary equipment and material support.

\section{REFERENCES}

${ }^{1}$ O. Çavuşoğlu, H. Gürün, Investigation of the effects of deformation speed on the mechanical properties and deep drawing process of DP600 and DP780 sheet metal, Journal of the Faculty of Engineering and Architecture of Gazi University, 29 (2014) 4, 777-784, doi:10.17341/gummfd.76140

${ }^{2}$ N. Wang, Z. Zhou, G. Lu, Microstructural evolution of 6061 alloy during isothermal heat treatment, J. Mater. Sci. Technol., 27 (2011) 1, 8-14, doi:10.1016/S1005-0302(11)60018-2

${ }^{3}$ B. M. Dariani, H. G. Liaghat, M. Gerdooei, Experimental investigation of sheet metal formability under various strain rates, Proc. IMechE Part B: J. Engineering Manufacture, 223 (2009), 703-712, doi:10.1243/09544054JEM1430

${ }^{4}$ C. Kubat, A. Kiraz, The modeling of tensile test in virtual laboratory design using artificial intelligence Journal of the Faculty of Engineering and Architecture of Gazi University, 27 (2012) 1, 205-209, doi:10.17341/gummfd.04550

${ }^{5}$ J. Q. Tan, M. Zhan, S. Liu, T. Huang, J. Guo, H. Yang, A modified Johnson-Cook model for tensile flow behaviors of 7050-T7451 aluminum alloy at high strain rates, Materials Science \& Engineering A, 631 (2015), 214-219, doi:10.1016/j.msea.2015.02.010

${ }^{6}$ M. Vural, J. Caro, Experimental analysis and constitutive modeling for the newly developed 2139-T8 alloy, Materials Science and Engineering A, 520 (2009), 56-65, doi:10.1016/j.msea.2009.05.026

${ }^{7}$ R. Smerd, S. Winklera, C. Salisburya, M. Worswicka, D. Lloydb, M. Finn, High strain rate tensile testing of automotive aluminum alloy sheet, International Journal of Impact Engineering, 32 (2005), 541-560, doi:0.1016/j.ijimpeng.2005.04.013

${ }^{8}$ O. G. Lademo, O. Engler, J. Aegerter, T. Berstad, A. Benallal, O. S. Hopperstad, Strain-rate sensitivity of aluminum alloys AA1200 and AA3103, J. Eng. Mater. Technol., 132 (2010) 4, 041007-8, doi:10.1115/1.4002160

${ }^{9}$ D. Li, A. Ghosh, Tensile deformation behavior of aluminum alloys at warm forming temperatures, Materials Science and Engineering A, 352 (2003), 279-286, doi:10.1016/S0921-5093(02)00915-2

${ }^{10}$ Material Properties: Determination of Process Limitations in Sheet Metal Forming - Forming Limit Diagram, gom Optical Measuring Techniques, http://www.gom.com/fileadmin/user_upload/industries/ flc_fld_EN.pdf, 18.06.2015

${ }^{11}$ O. Anket, T. Koruvatan, İ. Ay, The use of forming limit diagrams in forming sheet metal materials, Journal of Polytechnic, 14 (2011) 1, 39-47

${ }^{12}$ C. Zhang, X. Chuc, D. Guinesd, L. Leotoing, J. Dinga, G. Zhao, Effects of temperature and strain rate on the forming limit curves of AA5086 sheet, Procedia Engineering, 81 (2014), 772-778, doi:10.1016/j.proeng.2014.10.075

${ }^{13}$ C. Zhang, L. Leotoing, D. Guines, E. Ragneau, Theoretical and numerical study of strain rate influence on AA5083 formability, Journal of Materials Processing Technology, 209 (2009), 3849-3858, doi:10.1016/j.jmatprotec.2008.09.003

${ }^{14}$ T. Naka, G. Torikai, R. Hino, F. Yoshida, The effects of temperature and forming speed on the forming limit diagram for type 5083 aluminum-magnesium alloy sheet, Journal of Materials Processing Technology, 113 (2001), 648-653, doi:10.1016/S0924-0136(01) 00650-1 